\title{
A Case Study of Solutions to Some Intonation Mistakes Made by Vietnamese Students - A Phonetic Experimental Research
}

\author{
Tran Thi Thanh Dieu \\ Faculty of English Linguistics and Literature, University of Social sciences and Humanities, Viet Nam National University - Ho Chí Minh city, \\ Vietnam
}

Email address:

thdieu2003@yahoo.com, thanhdieutt@hcmussh.edu.vn

To cite this article:

Tran Thi Thanh Dieu. A Case Study of Solutions to Some Intonation Mistakes Made by Vietnamese Students - A Phonetic Experimental Research. International Journal of Language and Linguistics. Vol. 3, No. 2, 2015, pp. 52-60. doi: 10.11648/j.ijl1.20150302.13

\begin{abstract}
This study focuses on the importance of combining phonological knowledge with rhythm, melody and syntax rules in teaching English intonation affected by stress for Vietnamese students, verified by Experimental Phonetics. The hypothesis is that the English Rhythmic patterns and melodic aspect will help students to identify their intonation mistakes and change from negative to positive attitude towards practicing intonation melodically affected by stress. The final target is to improve Vietnamese students' pronunciation skill as well as catching the main idea in the conversation in order to have successful communication in English.
\end{abstract}

Keywords: English Rhythmic Patterns, Melody, Syntactic rules, Stress, Intonation, Phonetic Experiment

\section{Introduction}

“Teacher, why doesn't our speech sound like English?” asked my students. This is the questions I heard so many times and after many nights had been spent thinking, finally the answer appeared in my mind, that is 'rhythm and melody'. Now that every language in the world has a characteristic speech rhythm. English tends to be a stress-timed language with rhythmic patterns based on a fairly regular recurrence of stressed syllables [3]. However, Vietnamese tends to give equal weight to each syllable, making the rhythmic patterns appear to be more syllable-timed [19], [29], [31]. Moreover, the native speakers always speak English with melody [3]. As a result, many students often use the Vietnamese rhythmic pattern when speaking English without melody; therefore, even though they can pronounce each English sound correctly, their speech doesn't sound like English.

To solve this problem, it is important for our students to know the different rhythmic patterns of Vietnamese and English. The teacher can show the contrast between the two languages to indicate that Vietnamese is syllable-timed while English is stress-timed and try the method of combining the phonological knowledge, the English rhythmic patterns and melody to teach prosody for Vietnamese students.

Nobody would think of questioning the advantages of this strategy, but passive student is a vexed question. I strongly believe in the effect of this strategy on passive students. However, as a proverb goes: "Seeing is believing", I'd like to do a research to prove the advantage of this strategy with the hope to convince teachers to use this strategy in teaching prosody, especially stress and intonation, one of the main factors to achieve or to lose success although "it is not easy to help students be accustomed to Rhythm and Melody, the first step to enter the music house, the human's soul" as many teachers have said.

\section{Methodology}

The research was conducted for twenty-four weeks from September 2010 to February 2011 with six weeks for preparation and choosing population, twelve-week trial teaching, one week for testing and three weeks for survey as well as the last two weeks for data analysis. The method used in the research is the comparative strategy based on the prosodic analysis of Rhythmic patterns through melody between English and Vietnamese, the Combination of Quantitative approach to Check and compare the score, and Qualitative approach through the Questionnaire to check 
students' feeling, together with the Phonetic Experiment.

\subsection{Variables}

The Research is largely the study of what happens when variables are systematically manipulated in planned combinations. In my research, Variables play the following roles

\subsubsection{Dependent Variable}

Some basic sentence patterns illustrating the English Rhythmic patterns and melody, the test-score to be compared after trying the two different strategies (the ordinary = only teach phonological knowledge and the strategy of combining phonological knowledge and rhythm through melody in teaching English intonation called the treatment). Inasmuch as to find out and prove the effect of the treatment (answer the question "what is the effect of the treatment on passive students), the best way is comparing the score of the group receiving the treatment called experimental group, with the other group that doesn't receive the treatment, this second group is the control group.

\subsubsection{Independent Variable (Manipulated Variable)}

The strategy of combining phonological knowledge, rhythm and melody in teaching English intonation, which have been selected in order to study its effect on the dependent variable.

\subsection{Participants}

The research was carried out with 90 Vietnamese students who were from 2 kinds of source - University of Social Sciences and Humanities - BA course in English, and HCMC Open University, called "population" (in order to ensure the reliability of the effect of a strategy (practicing the English Rhythmic patterns and melody), chosen by being checked 2 phonetic Tests and divided into three control groups that is being taught by only providing the phonetic and phonological knowledge and three experimental groups which received treatment that is being taught by using English Rhythmic patterns and melody to practise the phonetic and phonological knowledge already provided, to find out the effect of using English Rhythmic patterns and melody to practise the phonetic and phonological knowledge already provided on improving students' ability on recognizing and exact pronunciation of intonation patterns. Then samples of the students population were recorded their pronunciation of some phonetic tests on intonation and surveyed by questionnaire about their thinking of the English Rhythmic patterns and Melody to find out if there are any changes in students' attitudes towards English intonation after the method was used. Students will simply be providing their judgments and Checklist of Colleagues' observation and criticizing. Analysis of the experimental and survey data, verified by phonetic experiment, checked whether students who received the treatments made lots of progress in intonation pronunciation skill as well as changing from negative to positive attitude towards English intonation.

However, the population is clearly identified with the salient characteristics, called strata, which is that the population must be at the same passive level, and chosen by checking as follow:

2 classes were chosen from 2 sources above. In every class, all of the students had to do 2 phonetic Tests on intonation (Multiple-choice and oral Test). 30 students who had the same lowest mean (of the 2 phonetic tests) are chosen. The sampling technique used is Stratified random sampling.

30 students chosen in every class were divided into 2 groups randomly on the basic of a table of random number: 15 participants for control group (which was used to try the ordinary strategy to teach intonation) and 15 participants for experimental group (which was used to try the treatment to teach), called "sample".

About the ethical consideration, to prevent from having bad effect on the students in the control group, Students in both groups (Control group and Experimental group) were just informed that they are participating in the Research with the two different types of strategies, without knowing which is better.

\subsection{Materials}

The comparison between the English and Vietnamese Rhythmic patterns and melody, the techniques for teaching the English Rhythmic patterns and melody, homework assignment, worksheets, class materials. Many of these provide primarily action data since they show what students have done. They are very valuable in helping teachers address problems that involve individual students and their progress in what they are learning. This kind of materials also provide a way of checking to see whether or not teachers have used an effective method, the strength and weakness of the treatment: teaching by using the treatment.

The sentence sample were recorded from the CD ROM of the Cambridge Book for Cambridge Exam - Examination paper from University of Cambridge ESOL Examination IELTS 5 - Cambridge University Press, called standard pronunciation: RP (Received/ Standard pronunciation, called CPAC in Vietnamese) and from the population (students), called investigated samples ( $\mathrm{T}$ (Token: investigated samples, called MKS in Vietnamese), which was analyzed and illustrated by SPEECH ANALYZER (Copyright (C) 1996-2007 by SIL International) and PRAAT 5.05.12. (copyright @ 1992-2008 by Paul Boersma and David Weenink).

\section{Data Analysis and Finding}

Analysis of the English-Vietnamese rhythmic patterns and melody, the experimental and survey data, verified by phonetic experiment, indicated that students who received the treatments made lots of progress in sentence intonation pronunciation skill as well as changing from negative to positive attitude towards English intonation, illustrated as follows: 


\subsection{Comparison of the English and Vietnamese Tone Unit Through Rhythmical Patterns, Melody and Intonation Rules}

Every language in the world has their own speech rhythmic pattern. English is a Stress-timed language, [24] with the rhythmic pattern based on the regular repetition of the stressed syllables. Whereas, Vietnamese tends to have the equal syllable to form the Rhythmic patterns of the Syllable-timed language, with the syllables having the equal intensity. The difference mentioned above leads to the fact that although Vietnamese students can pronounce the English sounds exactly, their speech does not sound like English now that they can not reach to the characteristics of 'strong' and 'weak' to form the rhythm with the pitch contour as melody. Therefore, the time has come when the teachers spend more time emphasizing the difference between English and Vietnamese rhythmic patterns, as follows.

Table 1. Comparison of the English - Vietnamese Rhythmic Patterns and Intonation Rules.

\begin{tabular}{|c|c|c|}
\hline & ENGLISH RHYTHMIC PATTERN & VIETNAMESE RHYTHMIC PATTERN \\
\hline Type of language & $\begin{array}{l}\text { Stress-timed language, with the rhythmic pattern based } \\
\text { on the regular repetition of the stressed syllables }\end{array}$ & $\begin{array}{l}\text { Syllable-timed language, with the syllables having the equal } \\
\text { intensity, }\end{array}$ \\
\hline Pattern & $\{\mathrm{F}=[\mathrm{S} \mathrm{W}]\}$ & $\{\mathrm{N}=[\mathrm{A}]\}$ \\
\hline Meaning of the abreviation & $\begin{array}{l}\mathrm{F}=\text { Foot } \\
\mathrm{S}=\text { strong } \\
\mathrm{W}=\text { weak }\end{array}$ & $\begin{array}{l}\mathrm{N}=\text { nhịp }(\text { Rhythm) } \\
\mathrm{A}=\text { âm tiết (Syllable) }\end{array}$ \\
\hline Intonation rules & Stipulated by syntactic rules & Constrained by Vietnamese tone \\
\hline
\end{tabular}

The tone - unit has a place in a range of phonological units that are in a hierarchical relationship:

- Speech consists of a number of utterances

- $\quad$ Each utterance consists of one or more tone-units
- $\quad$ Each tone-unit consists of one or more feet

- $\quad$ Each foot consists of one or more syllables

- Each syllable consists of one or more phonemes

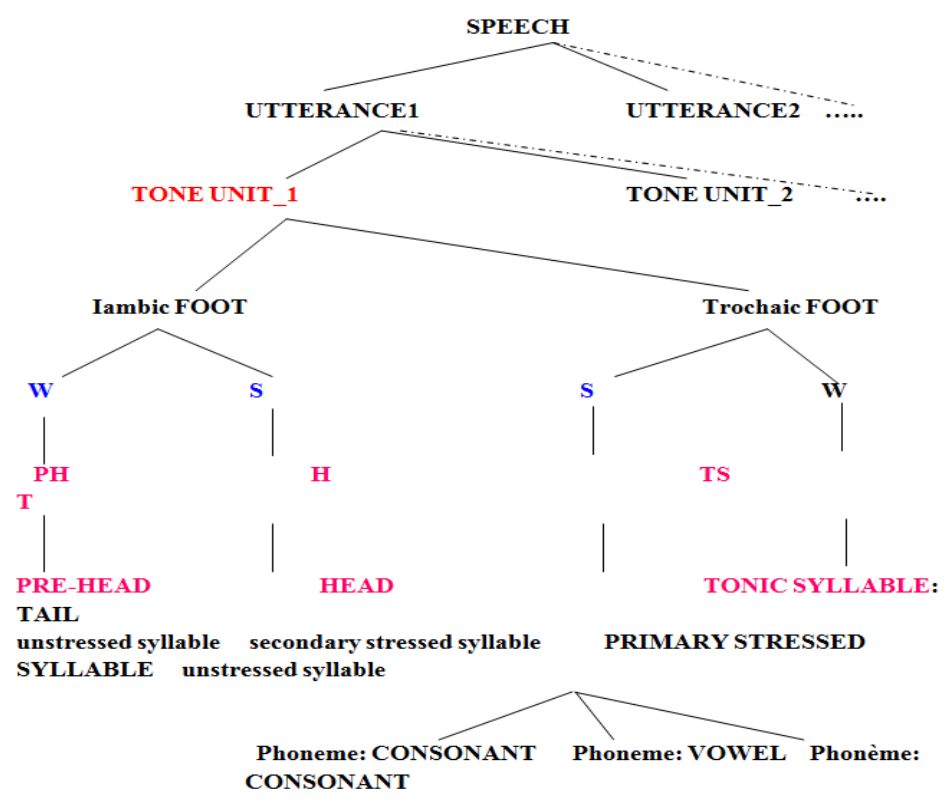

Note $: \mathrm{S}:$ TRONG $=$ Heavy syllable $=$ stressed syllable. $-\mathrm{W}: \mathrm{WEAK}=$ Light syllable $=$ unstressed syllable

Figure 1. Analysis of a tone unit in English intonation.

The foundation of the English rhythmic pattern is the existence of the 2 types of syllable: heavy and light syllable. A light syllable contains only a short vowel in the rhyme, with no coda, as in the rest syllable of potato, report, about. Although the rest two cases have onsets, and the third does not, all these initial syllables are still light, because onsets are entirely irrelevant to the calculation of syllable weight [24]. If a syllable has a complex rhyme, then it is heavy; and complexity can be achieved in two different ways. First, a heavy syllable may have a short vowel, but one or more coda consonants, as in bet, best. Second, it may have a branching nucleus, consisting of a long vowel or diphthong; such a syllable will be heavy whether it also has a bled coda, as it put by the Cambridge advance learner dictionary - third edition "when a word or syllable is pronounced with greater force than other words in the same sentence or other syllables in the same word, it is stressed", as well as Fry $(1955,1958)$ 's identified the intensity over the syllable as a possible acoustic correlate of stress differences.

In addition, the speaker's use of intonation, the rise and fall 
of the pitch of the voice, to convey sarcasm or resignation, anger or apprehension, or any of scores of other moods. Therefore, the work looks at both accent (pitch shift that points up individual words) and overall configurations (melodies that shape the meaning of whole sentences). The pitch of the voice plays the most important part. The pitch is described in terms of high and low. It shows that most easily understood utterances employ one or another of a surprisingly small stock of basic melodies, and it shows both intonation and visible gesture to be parts of a larger complex that conveys grammatical as well as emotional information [3].

As a result, intonation helps us to understand a speaker's feelings, a speaker's attitude, whether a speaker is asking us a question, whether a speaker is done and it's our turn to say something.

\subsection{Phonetic Experiment}

\subsubsection{Phonetic Experiment Proving the Pronunciation Mistake on Rhythm and melody in English Intonaion Made by a Vietnamese Student}

A spectrogram as the one below is created by displaying all of the spectra computed from the speech waveform together. The vertical axis in a spectrogram represents frequency, with 0 $\mathrm{Hz}$ at the bottom. The lines visible in the spectrogram on this page each represent $1000 \mathrm{~Hz}$ along the frequency axis, so that the spectrogram contains $8000 \mathrm{~Hz}$ in total. All of the spectra computed by the Fourier transform are displayed parallel to this vertical or $y$-axis. The horizontal axis represents time; as we move right along the $\mathrm{x}$-axis we shift forward in time, traversing one spectrum after another. Spectrograms are normally computed and kept in computer memory as a two-dimensional array of acoustic energy values. For a given spectrogram $S$, the strength of a given frequency component $f$ at a given time $t$ in the speech signal is represented by the darkness or color of the corresponding point $S(t, f)$. Therefore, RP (Received/ Standard pronunciation) and $\mathrm{T}$ (Token: investigated samples) feature are shown.

Based on the complex rules for English intonation, we investigated the tag question 'Shall I bring a bank statement, would that do?', with stress on the tonic syllable 'that' and final syllable 'do' in a tone unit of the tag ...., would that do?' since 'that' is not demonstratives, but pronoun reference. In addition, this sentence has two types of syntactic category: Tag question and Echo question, which are difficult with complex intonation rule. Therefore, this Tag question has the function of asking for information, the voice raised at the end.

The sentence Shall I bring a bank statement, would that do? was recorded and investigated by experimental phonetics provided the result of the Pitch and Intensity comparison in the following spectrogram figures.

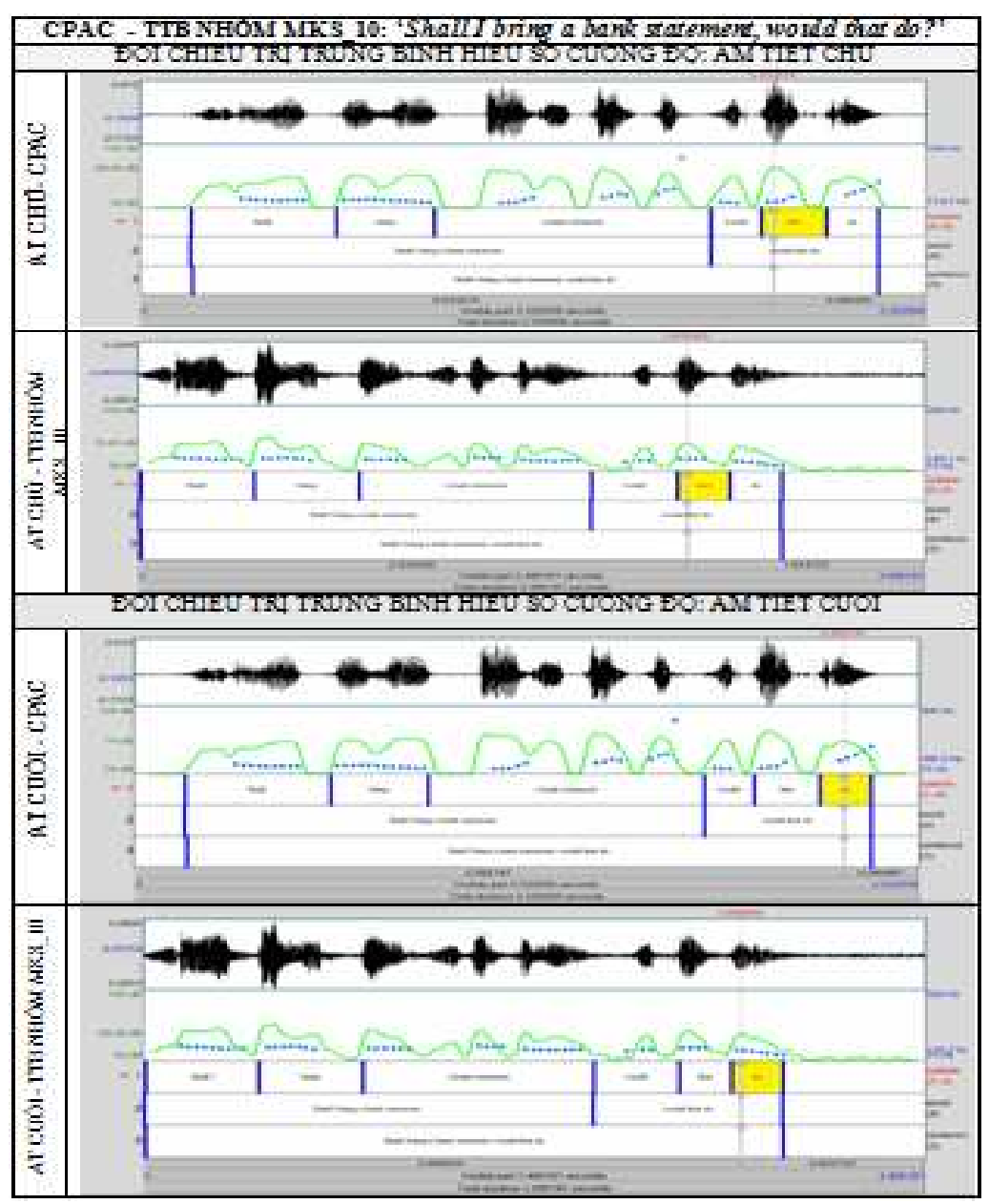

Figure 2. Spectrogram of the Pitch and Intensity comparison between RP and T. 
The analysis result is illustrated in the Table: Intensity and sample based on the types of Intonation mistake, as follows Pitch Comparison among the ten groups of investigated

Table 2. Intensity and Pitch mean of RP and T in the phonetic experiment.

\begin{tabular}{|c|c|c|c|c|c|c|c|}
\hline \multirow{2}{*}{ No } & \multirow{2}{*}{ Mistake-type Group } & \multicolumn{3}{|l|}{ Intensity mean } & \multirow{2}{*}{\multicolumn{2}{|c|}{$\begin{array}{l}\text { Mistake-type and the number } \\
\text { of Token in every group/ } 100\end{array}$}} & \multirow{2}{*}{$\begin{array}{l}\text { Pitch Difference } \\
\text { mean }\end{array}$} \\
\hline & & TONIC syllable & Final Syllable & DIFFERENCE & & & \\
\hline CPAC & & $72.60 \mathrm{~dB}$ & $60.66 \mathrm{~dB}$ & $11.94 \mathrm{~dB}$ & EXACT & & $104.8 \mathrm{~Hz}$ \\
\hline 1 & Group MKS_8 & $69.24 \mathrm{~dB}$ & $67.05 \mathrm{~dB}$ & $0.81 \mathrm{~dB}$ & A & 07 & $53.7 \mathrm{~Hz}$ \\
\hline 2 & Group MKS_1 & $69.13 \mathrm{~dB}$ & $79.03 \mathrm{~dB}$ & $-10.3 \mathrm{~dB}$ & B & 11 & $59.4 \mathrm{~Hz}$ \\
\hline 3 & Group MKS_7 & $62.14 \mathrm{~dB}$ & $65.05 \mathrm{~dB}$ & $-2.91 \mathrm{~dB}$ & $A+B$ & 23 & $46.5 \mathrm{~Hz}$ \\
\hline 4 & Group MKS 5 & $71.26 \mathrm{~dB}$ & $62.25 \mathrm{~dB}$ & $10.01 \mathrm{~dB}$ & $\mathrm{C}$ & 08 & $-73.5 \mathrm{~Hz}$ \\
\hline 5 & Group MKS_10 & $73.11 \mathrm{~dB}$ & $70.01 \mathrm{~dB}$ & $3.1 \mathrm{~dB}$ & $\mathrm{~A}+\mathrm{C}$ & 10 & $-57 \mathrm{~Hz}$ \\
\hline 6 & Group MKS_1 & $66.22 \mathrm{~dB}$ & $71.39 \mathrm{~dB}$ & $-5,17 \mathrm{~dB}$ & $\mathrm{~B}+\mathrm{C}$ & 12 & $-63.1 \mathrm{~Hz}$ \\
\hline 7 & Group MKS_9 & $69.28 \mathrm{~dB}$ & $72.01 \mathrm{~dB}$ & $-2.73 \mathrm{~dB}$ & $\mathrm{~A}+\mathrm{B}+\mathrm{C}$ & 25 & $-53.6 \mathrm{~Hz}$ \\
\hline 8 & Group MKS_6 & $68.03 \mathrm{~dB}$ & $60.01 \mathrm{~dB}$ & $8.02 \mathrm{~dB}$ & NEARLY EX & 03 & $69 \mathrm{~Hz}$ \\
\hline 9 & Group MKS 2 & $71.55 \mathrm{Db}$ & $60.41 \mathrm{~dB}$ & $11.14 \mathrm{~dB}$ & EXACT & 01 & $63.2 \mathrm{~Hz}$ \\
\hline
\end{tabular}

Comparison between the intensity of tonic and final syllable - RP (CPAC) and 9 groups of tokens (nhóm mks 1-9)

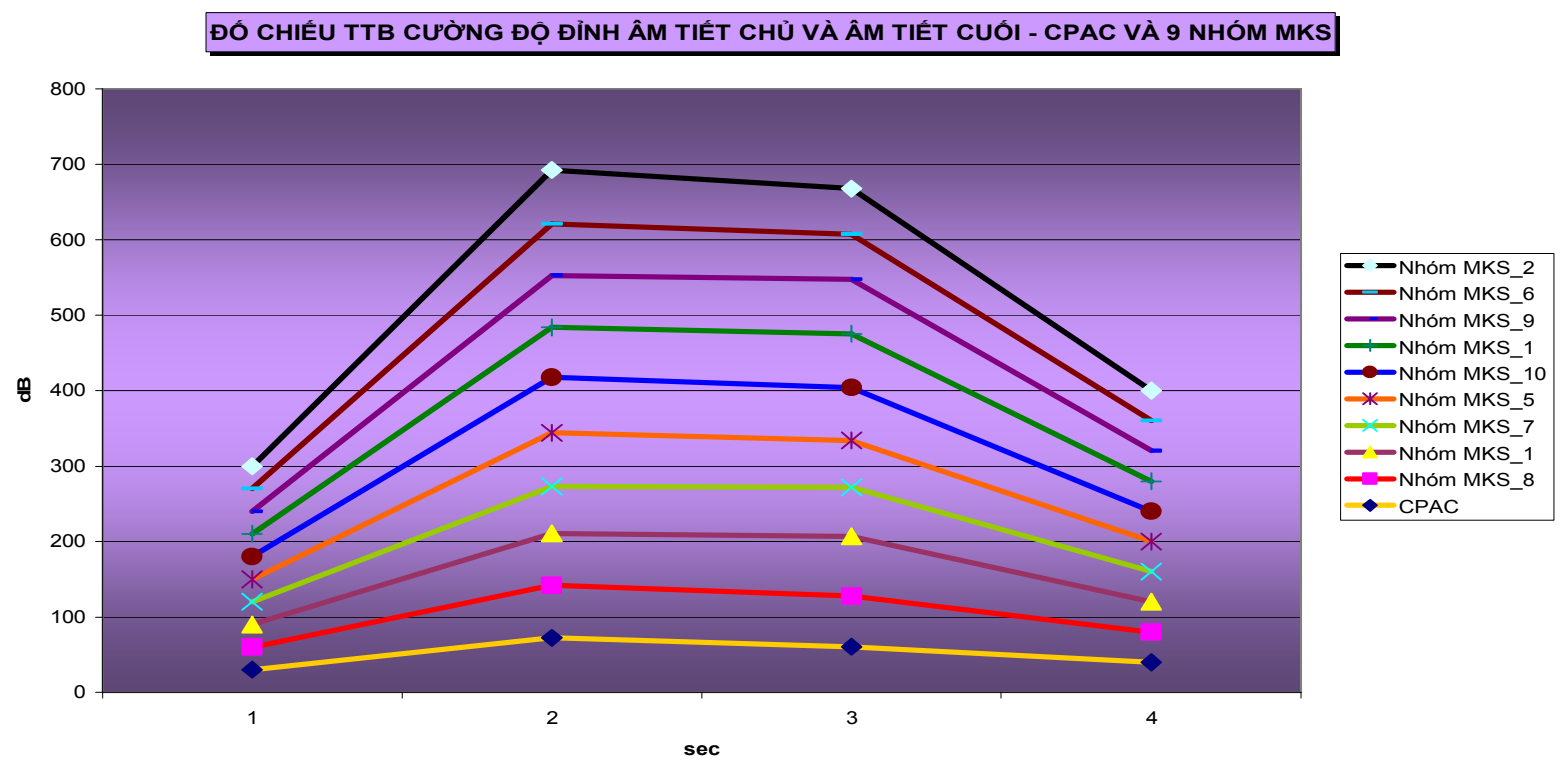

Figure 3. Comparison between RP Intensity and intensity difference among 9 TOKEN groups: Shall I bring a bank statement, would that do?

According to the number in the table and the spectrogram figures above and as it put by the Cambridge advance learner dictionary - third edition "when a word or syllable is pronounced with greater force than other words in the same sentence or other syllables in the same word, it is stressed", as well as Fry $(1955,1958)$ 's identified the intensity over the syllable as a possible acoustic correlate of stress differences, the intensity of RP (CPAC) at the tonic syllable peak is 72.60 $\mathrm{dB}$ and at the final syllable peak is $62.66 \mathrm{~dB}$, therefore, we can have the conclusion that RP (CPAC) pronounced with a greater energy at the tonic syllable than at the final syllable $(72.60 \mathrm{~dB}-62.66 \mathrm{~dB}=9.94 \mathrm{~dB})$ and made the English rhythm pattern as $\{\mathrm{F}=[\mathrm{S} \mathrm{W}]\}$. Whereas the intensity of $\mathrm{T}$ group MKS_10 at the tonic syllable peak is $73.11 \mathrm{~dB}$ and at the final syllable peak is $70.01 \mathrm{~dB}$, nearly the same intensity at the peak of the stressed and final syllable $(73.11 \mathrm{~dB}-70.01 \mathrm{~dB}=3.1$ $\mathrm{dB})$, which is a serious mistake caused by the influence of Vietnamese mother tongue, called interfering mistake in language with the Vietnamese rhythmic pattern as $\{\mathrm{N}=[\mathrm{A}]\}$. In addition, T Group MKS_10 has the TTB HS (the difference mean) of the pitch between the final syllable peak - Tonic syllable peak $=-57 \mathrm{~Hz}$, showing that the population (CTV) pronounced with wrong intonation pattern. The right pattern for a tag question with real interrogative purpose is pattern 2-3, with the tag would that do must be raising. Therefore, this group was chosen to compare with CPAC (RP), illustrated in the spectrogram figures. This (T) MKS group with the proportion $9.01 \%$, having the Pitch difference mean $=-0.57$ $\mathrm{Hz}<0$ so they have the characteristics of not only the intonation mistake pattern but also Rhythmical mistake pattern since Intensity difference mean $=3.1 \mathrm{~dB}<5$, not to adapt the Rhythmical aspect.

\subsubsection{Types of Intonation Mistake}

Therefore, in general, we have discovered seven types of English intonation mistake when Vietnamese students pronounce a fragment/ tone unit. 
Type 1: Mistake of rhythmic pattern (A). Even though students identify stress on the right syllable, they pronounce each syllable with equal force to make the intensity difference between the peak of 2 or 3, 4 the syllables zero, or just a minor difference.

Type 2: Mistake of tonic syllable identification $(B)=$ not stress on the tonic syllable. Students place stress on the wrong syllable.

Type 3: Mistake of rhythm and tonic syllable identification $(\mathrm{A}+\mathrm{B})$. Students neither place stress on right syllable nor adapt the rhythmical pattern S_W (S: Strong, W: weak).

Type 4: Mistake of intonation pattern (C). Students make wrong pitch contour due to being unable to identify the intonation pattern in which this kind of sentence should be pronounced with raising or lowing voice.

Type 5: Mistake of rhythmic and intonation pattern $(A+C)$. Students neither adapt the rhythmic patterns nor intonation patterns.

Type 6: Mistake of tonic syllable identification and intonation pattern $(B+C)$. Students neither stress on the tonic syllable of a tone unit nor adapt the intonation patterns

Type 7: Mistake of rhythm, tonic syllable identification and intonation pattern $(A+B+C)$. The combination of the three types of mistake: rhythmical pattern (A), tonic syllable identification (B) and intonation pattern (C): students place stress on the wrong syllable, can not pronounce with rhythm (the intensity difference between the peaks of 2 or 3, 4 the syllables are zero, or just a minor difference) and make the wrong pitch contour.

\subsubsection{Solution}

Rhythm is so important to language with multi-syllabic word that children have to learn the rhythm of their L1 very early in life [14]. By the time they reach the age of one, that rhythm is deeply familiar to them, and they will unconsciously apply it to any L2 that they learn (Aoyama et al. 2007). Since English learners will be predisposed to use the rhythm of their
L1, it is highly important that they be made consciously aware of the English system of rhythm. The basic unit of English rhythm is the syllable. A syllable is most simply explained as something with a vowel sound at its center. And while the number of syllables in a word is usually obvious to a native speaker of English, learners accustomed to different phonological rules may not hear the syllable divisions in the same way. Since this seriously affects both intelligibility and listening comprehension, time must be spent training students' ears to notice the number of syllables in the words they learn.

Precisely, Vietnamese rhythmic pattern does not have the differences in intensity between stressed and unstressed syllables; on the contrary, English rhythmic pattern has differences in intensity (of course also in pitch and vowel duration). As a result, to be affected by this mother-tongue characteristics, Vietnamese students are not aware of the importance of syllable weight, shown through intensity, the main cue to identify English word stress, which decide the ability to catch the accurate information based on the main syllable of a word, which is not only the stressed syllable but also the tonic syllable in a tone unit. Therefore, teachers should spend more time training students how to count the number of syllable in a word, identify the syllable weight (strong syllable $=$ stressed syllable and weak syllable $=$ unstressed syllable) to be able to follow the English rhythmic pattern when pronouncing the English multi-syllabic words.

Especially, when pronouncing intonation, speakers must pay attention to the melody, illustrated by the pitch contour based on the intonation rules to adapt to English language.

\subsection{Experimental Research}

\subsubsection{The Average Point of the 2 Test of 2 Groups of 3 Classes}

Data was analyzed by using Microsoft Excel as the most useful tool.

Table 3. The score of the three Participant sources.

\begin{tabular}{|c|c|c|c|c|c|c|}
\hline \multicolumn{7}{|c|}{ The score of three sources of participants } \\
\hline \multirow{2}{*}{ No of Ss } & \multicolumn{2}{|l|}{ Class1 } & \multicolumn{2}{|l|}{ Class2 } & \multicolumn{2}{|l|}{ Class3 } \\
\hline & Experimental group & Control group & Exp - group & Cont - group & Exp - group & Cont - group \\
\hline 1 & 70 & 35 & 50 & 60 & 65 & 40 \\
\hline 2 & 70 & 60 & 80 & 60 & 70 & 60 \\
\hline 3 & 80 & 50 & 65 & 40 & 65 & 40 \\
\hline 4 & 70 & 40 & 70 & 50 & 70 & 45 \\
\hline 5 & 70 & 60 & 75 & 50 & 70 & 50 \\
\hline 6 & 80 & 35 & 80 & 45 & 80 & 45 \\
\hline 7 & 75 & 40 & 75 & 50 & 60 & 45 \\
\hline 8 & 65 & 60 & 65 & 60 & 65 & 60 \\
\hline 9 & 70 & 40 & 65 & 40 & 70 & 40 \\
\hline 10 & 60 & 45 & 60 & 35 & 60 & 45 \\
\hline 11 & 80 & 40 & 80 & 50 & 70 & 40 \\
\hline 12 & 70 & 30 & 70 & 45 & 70 & 43 \\
\hline 13 & 85 & 45 & 85 & 50 & 85 & 60 \\
\hline 14 & 60 & 55 & 60 & 55 & 70 & 55 \\
\hline 15 & 75 & 50 & 70 & 65 & 75 & 45 \\
\hline
\end{tabular}

\subsubsection{Comparison of LC Ability of Experimental and Control Group}


Table 4. Comparison of LC ability of Experimental and Control group.

\begin{tabular}{lllllll}
\hline & Class1 & & Class2 & & Class3 \\
\cline { 2 - 7 } & Experimental group & Control group & $\begin{array}{l}\text { Experimental } \\
\text { group }\end{array}$ & Control group & Experimental group & Control group \\
\hline Mean & 7.2 & 4.5 & 7 & 5.4 & 7 & 4.8 \\
Standard Deviation & 7.222998 & 4566667 & 7.015877 & 5355555 & 6966667 & 4753333 \\
Range & 25 & 20 & 25 & 20 & 25 & 20 \\
\hline
\end{tabular}

\subsubsection{Diagram of the Tests' Result}

\section{MEAN OFTHREE CLASSES}

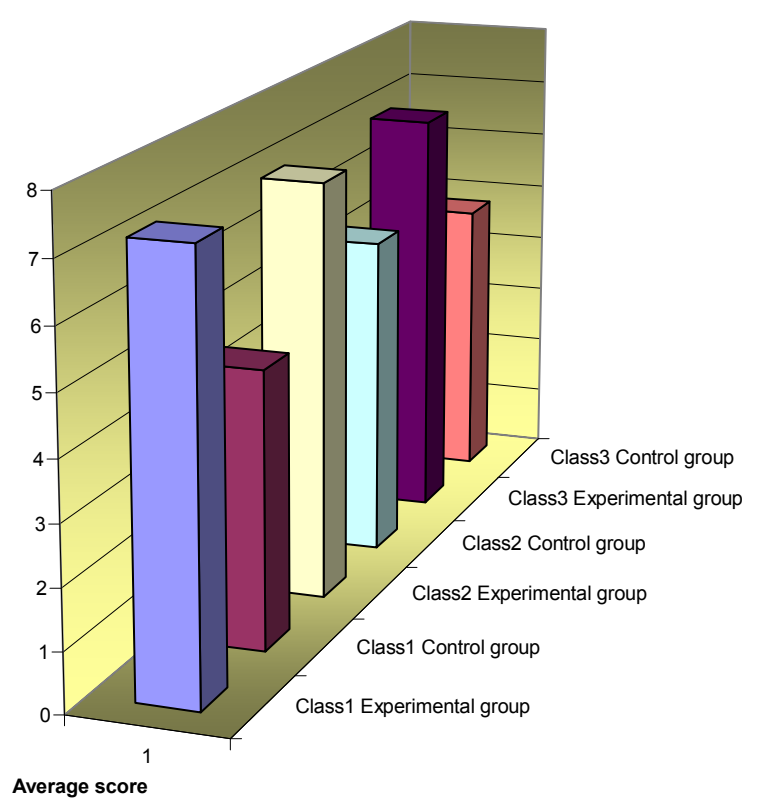

Figure 4. Score mean of the three classes.

From the diagram above, the result of the three classes in the control group were nearly the same and lower than the result of the experimental group. It showed the effect of the treatment used to train the experimental group.

\subsection{Survey Research: Questionnaire Analysis}

\subsubsection{The Effect of Combining Phonological Knowledge, Rhythm and Melody in Teaching English Intonation Strategy}

To be accustomed to the English Rhythmic patterns, and melody (although just a little because of short term training for this research) has made the students' speech more natural as the native speakers and the content they want to express has become clearer and easier for their partners to catch the main idea, leading to quite successful communication. This finding brings the conclusion that the treatment used in this research is the procedure that can be used with nonfiction selections at any grade level and in any content learning situation and can help learners to access the knowledge they already have or make it available appropriately so that comprehension can occur.

All this intonation practice through rhythm and melody activity developed the students' own ability to find the answer to the question happening during the conversation that will increase their reservoir of knowledge on this topic. With the
English Rhythmic patterns and Melody, students seemed to be more active and interested in the intonation lesson. Group activity gave student's natural atmosphere, free from the teacher-watching pressure, Step by step the passive students showed their self-confidence.

Having to find out what still need to discover during the practice-conversation provided students purpose for trying to listen and catch main ideas based on the melody and the pause made by rhythm, made them feel enjoyable of interaction, the main reason for activeness during the conversation. Moreover, some students could help their friends by repeating some parts in the conversation to activate prior knowledge themselves and help their friends become more self-confident. Therefore, they were not afraid of communication anymore and did extra activity in practicing intonation through rhythm and melody outside the classroom to help them improve their speaking skill effectively.

This is one of the most suitable to the passive students. In the other word, this strategy makes students feel interested in communicating in English, especially the melody and the pause made by rhythm, the best ways to collect schemata, being suitable to a current perspective on comprehension: the communication process is an interaction between a speaker's prior knowledge and the information encoded in the conversation. The interactive model has recently been studied 
under the rubric of schema theory. This theoretical framework emphasizes that the speaker is an active participant who can contribute to the construction of meaning. When students interpreter the conversation in light of their previous knowledge and simultaneously modify their original schemata as new information is learned.

\subsubsection{Students' Thinking of the Treatment \& Students' Attitude Towards English Intonation}

Although students found some difficulties in being accustomed to melody and English Rhythmic patterns, some techniques for practising intonation based on stress through rhythm, relating the ability of music, discussion raising question, developing personal commitment... as well as remembering what they heard during the conversation, judging the kinds of variation existing in different topics, pursue your own quest for knowledge, the partners' opinions...., they showed their interest in this strategy and as a result, their attitude towards English intonation had some change. Maybe Prosody class isn't the time of sleeping anymore. The teachers who teach pronunciation can forget the name "Dr. Anesthetist" and the most important result gained is the usefulness of the knowledge, and interacting skill provided to students from the interest in pronunciation. Inasmuch as the useful people with enough knowledge and skillful communication can raise the country to a higher position in the world.

\section{Conclusion}

Without a sufficient, threshold-level mastery of the English prosodic system, learners' intelligibility and listening comprehension will not advance, no matter how much effort is made drilling individual sounds. That is why the highest priority must be given to rhythm and melody in whatever time is available for teaching pronunciation [30]. However, in a limit time of training (three months from week 7 to week 18 in the twenty-four-week research process that was equal to a semester teaching), the teacher could not train all the students skill of practicing intonation based on English word stress in Rhythm, just some students could master some ways using Rhythm and speak with melody so they were not afraid of praising intonation as well as apply in real conversation outside the classroom to help them improve their ability to catch main idea in communication effectively.

From this study it is concluded that teachers should spend more time training students how to count the number of syllable in a word, identify the syllable weight (strong syllable $=$ stressed syllable and weak syllable $=$ unstressed syllable) to be able to follow the English rhythmic pattern when pronouncing the English multi-syllabic words and combine word to pronounce sentence with melody based on the intonation rules. In addition, more time should be given to the training process of this new strategy and more research is needed into how to use this strategy effectively to make students accustomed to applying this method, especially on their own independently for their extra communicative activity outside the classroom, one of the way to improve their exact prosodic speaking skill as well as their knowledge.

To sum up, following the proverb: "Seeing is believing", this research tried to prove the effect of the treatment. It also suggested a way to control a prosody class, to create an interesting and exciting atmosphere. Hopefully, this research will be one way of motivating teachers to overcome the difficulties when teaching prosody, especially stress and intonation and provide students opportunity to practice intonation based on English word stress through the English Rhythmic patterns with melody. Moreover, the treatment will be one of the ways to improve students' all basic skills in learning a language (reading, speaking, listening and writing); not only in English but also in all the languages they have opportunity to study, including their mother tongue to be successful in communication, especially in the process of globalization.

\section{References}

[1] Anderson, John M.; and Ewen, Colin J, Principles of dependency phonology. Cambridge University Press, 1987.

[2] Aoyama, K. \& S. Guion, Prosody in second language acquisition. Acoustic analyses of duration and FO range. In O.-S. Bohn \& M. Munro, eds. Language experience in second language speech learning. In honor of James Emil Flege, John Benjamins: 281-297, 2007.

[3] Bolinger, D. Intonation and Its Parts, Melody in Spoken English. Standford University Press, 1985.

[4] Brentari, Diane, A prosodic model of sign language phonology. Cambridge, MA: MIT Press, 1998.

[5] Nguyễn Tài Cẩn, Giáo trình lịch sử ngữ âm tiếng Việt. Nxb Giáo dục, 1997.

[6] Chomsky N and Halle M. 1968. The sound pattern of English. New York: Harper \& Row.

[7] Clements, George N, The geometry of phonological features. Phonology Yearbook, 2, 225-252, 1985.

[8] Clements, George N.; and Samuel J. Keyser, CV phonology: A generative theory of the syllable. Linguistic inquiry monographs (No. 9). Cambridge, MA: MIT Press. ISBN 0-262-53047-3 ISBN 0-262-03098-5, 1983.

[9] De Lacy, Paul, The Cambridge Handbook of Phonology. Cambridge University Press. ISBN 0-521-84879-2 (hbk), 2007.

[10] Nguyễn Công Đức, Nguyễn Hữu Chương, Từ vựng tiếng Việt. Tủ sách Đại học Khoa học Xã hội và Nhân văn, 2004.

[11] Fry D. B, Duration and intensity as physical correlates of linguistic stress. J. Acoust. Soc. Am. 27, 765-768. doi: 10.1121/1.1908022, 1955.

[12] Fry D. B, Experiments in the perception of stress. Lang Speech 1, 126-152, 1958.

[13] Fry D. B, The dependence of stress judgments on vowel formant structure. in Proceedings of the 5th International Congress of Phonetics Sciences, eds.Zwerner X., and Bethge W., Karger: Basel, pp. 306-311, 1965. 
[14] Nguyễn Thiện Giáp, Các phương pháp nghiên cứu ngôn ngữ. Nxb Giáo dục, 2009.

[15] Goldsmith, John A, "Phonological Theory". in John A. Goldsmith. The Handbook of Phonological Theory. Blackwell Handbooks in Linguistics. Blackwell Publishers, 1995.

[16] Goldsmith, John A, The aims of autosegmental phonology. In D. A. Dinnsen (Ed.), Current approaches to phonological theory. Bloomington: Indiana University Press, 1979.

[17] Griffee D. T. \& Nunan D, Classroom Teachers and Classroom research. Tokyo,Japan: The Japan Association for Language Teaching, 1997.

[18] Hadley G, Action Research in Action. Singapore: SEAMEO Regional Language Center, 2003.

[19] Cao Xuân Hạo, Tiếng Việt, mấy vấn đề Ngũ̃ âm, Ngữ pháp, Ngữ nghĩa. Nxb Khoa học Xã hội, 2006.

[20] Hatch E and Lazaraton A, University of California, The Research Manual Design and Statistics for Applied Linguistics. Boston: Heinle \& Heinle Publishers A Division of Wadsworth, Inc Boston, Massachusetts 02116, 1991.

[21] Nguyễn Quang Hồng, Âm tiết và loại hình ngôn ngữ. Nxb Đại học Quốc gia Hà Nội, 2002.
[22] Jones D, The pronunciation of English. Cambridge University Press, 2002.

[23] Ladefoged, Peter, A course in phonetics (4th ed.). Boston: Heinle \& Heinle, Thomson Learning, 2001.

[24] McMahon A, An introduction to English phonology. Edinburgh Univiersity Press, 1988.

[25] Roach, P, English Phonetics and Phonology. The Youth Press, Vietnam, 1998.

[26] SEAMEO Regional Language Center, Research Methodology Singapore: SEAMEO Regional Language Center, 2003.

[27] Spencer, A, Morphological Theory. Cambridge University Press, 1991.

[28] Stump,G,T, Inflectional Morphology - A theory of Paradigm Structure. Cambridge University Press, 2001.

[29] Lê Quang Thiêm, Nghiên cứu đối chiếu các ngôn ngữ. Nxb Đại học Quốc gia Hà Nội, 2004.

[30] Đinh Lê Thư, Nguyễn Văn Huệ, Cơ cấu ngữ âm tiếng Việt. Nxb Giáo dục, 1998.

[31] Đòan Thiện Thuật, Ngữ âm tiếng Việt. Nxb Đại học và Trung học chuyên nghiệp, 1980. 